\title{
SCREENING AND CHARACTERIZATION OF PHOSPHORUS SOLUBILIZING BACTERIA AND THEIR EFFECT ON RICE SEEDLINGS
}

\section{Md. Shahinur Rahman, Quazi Forhad Quadir*, Atiqur Rahman, Moonmoon Nahar Asha and Md. Abul Khair Chowdhury}

Department of Agricultural Chemistry, Faculty of Agriculture, Bangladesh Agricultural University, Mymensingh 2202, Bangladesh

*Corresponding author: Quazi Forhad Quadir, E-mail: qfq@bau.edu.bd

\section{$\begin{array}{ll}\text { ARTICLE INFO ABSTRACT } & \text { ABST }\end{array}$}

Received

25.10.2014

Accepted

17.12.2014

Online

27.12.2014

Key words:

Screening

Phosphorus fixation

Bacteria

Rice
An experiment was carried out to isolate, screen and characterize bacteria collected from an industrially polluted site of Bhaluka under the Mymensingh district and to evaluate their phosphorus ( $P$ ) solubilizing capacity. About ten plant and soil samples from six different spots were collected from the site. Thirty four bacterial isolates were screened and pure cultures of the different bacterial isolates were prepared. Among the bacterial isolates 25 were gram negative and 9 were gram positive. About 31 bacterial isolates had catalase producing capacity and remaining 3 were negative to catalase test. Bacterial isolates were grown on a NBRIP media to determine their phosphorus solubilizing capacity. About 25 bacterial isolates were shown $P$ solubilizing capacity. Isolate SB8 gave the highest result about 11.42 PSI (phosphorus solubilizing index), whereas other bacterial isolates showed moderate $P$ solubilizing capacity (PSI 1.75-6.35). A plant trial with selected isolates (SB8, SB15, SB25) were also done and SB8 achieved 10\% higher P content in comparison with control which supports the in vitro $\mathrm{P}$ solubilization assays.

To cite this article: Shahinur MR, QF Quadir, A Rahman, MN Asha and MAK Chowdhury, 2014. Screening and characterization of phosphorus solubilizing bacteria and their effect on rice seedlings. Res. Agric., Livest. Fish. 1(1): 27-35.

This article is an open access article licensed under the terms of the Creative Commons Attribution License.

www.agroaid-bd.org/ralf, e-mail: editor.ralf@gmail.com 


\section{INTRODUCTION}

Phosphorous $(P)$ is essential for growth and productivity of plants. It plays an important role in plants in many physiological activities such as cell division, photosynthesis, and development of good root system and utilization of carbohydrate. Phosphorous deficiency results in the leaves turning brown accompanied by small leaves, weak stem and slow development. In ancient times the use of animal manures to provide phosphorous for plant growth was common agricultural practice. Organically bound phosphorous enters in soil during the decay of natural vegetation, dead animals and from animal excretions. (Mahantesh and Patil, 2011) Plants might take up several $P$ forms but the greatest part of the applied $\mathrm{P}$ fertilizer is absorbed in the forms of $\mathrm{HPO}_{4}{ }^{2-}$ or $\mathrm{H}_{2} \mathrm{PO}_{4}{ }^{-}$ (Beever and Burns, 2000). It is the least mobile element in plant and soil compared to other macronutrients. The biggest reserves of $P$ are rocks and other deposits, such as primary apatites and other primary minerals formed during the geological age. Most agricultural soils contain large reserves of $\mathrm{P}, \mathrm{a}$ considerable part of which has accumulated as a consequence of regular applications of $P$ fertilizers (Richardson, 2001). Because of the negative charge of phosphate ions, they are quickly absorbed after weathering of clays or detritus particles, forming insoluble forms of aluminum, calcium, or iron phosphates, all unavailable to plants. In soil hydration and accumulation of hydrated oxides and hydroxides of Fe takes place, producing an increase of $\mathrm{P}$ fixation. Almost $75-90 \%$ of added $\mathrm{P}$ fertilizer is precipitated by $\mathrm{Fe}, \mathrm{Al}$ and $\mathrm{Ca}$ complexes present in the soils (Gyaneshwar et al., 2002).

Microorganisms are involved in a range of processes that affect the transformation of soil $\mathrm{P}$ and are thus an integral part of the soil $P$ cycle. In particular, soil microorganisms are effective in releasing $P$ from inorganic and organic pools of total soil $P$ through solubilization and mineralization (Hilda and Fraga, 1999). Currently, the main purpose in managing soil phosphorus is to optimize crop production and minimize P loss from soils. Recently, phosphate solubilizing microorganisms have attracted the attention of agriculturists as soil inoculums to improve the plant growth and yield (Fasim et al., 2002). Plant growth promoting bacteria (PGPB) are soil and rhizosphere bacteria that can benefit plant growth by different mechanisms (Glick, 1995) and P-solubilization ability of the microorganisms is considered to be one of the most important traits associated with plant $P$ nutrition. Given the negative environmental impacts of chemical fertilizers and their increasing costs, the use of PGPB is advantageous in the sustainable agricultural practices. It is generally accepted that the mechanism of mineral phosphate solubilization by PSB strains is associated with the release of low molecular weight organic acids (Kim et al., 1997), which through their hydroxyl and carboxyl groups chelate the cations bound to phosphate, thereby converting it into soluble forms (Kpomblekou and Tabatabai, 1994). However, P-solubilization is a complex phenomenon, which depends on many factors such as nutritional, physiological and growth conditions of the culture (Reyes et al., 1999). There is experimental evidence to support the role of organic acids in mineral phosphate solubilization (Halder et al., 1990). The present experiment was designed to screen potential PSB from industrially polluted soils of Seedstore, Bhaluka, Mymensingh for agricultural use and evaluate their physical and biochemical characteristics. An attempt was also made to determine their efficiency on the content and uptake of $P$ in a rice seedling.

\section{MATERIAL AND METHODS}

\section{Collection of samples}

To isolate rhizospheric bacteria from plant root, ten plant samples with their roots and soil samples from six different spots were collected from an industrially contaminated site Seedstore, Bhaluka under Mymensingh district. Immediately after collection, each sample was kept in labeled air tight plastic zipper bag and stored at $4^{\circ} \mathrm{C}$. 


\section{Isolation of the bacterial strains}

To isolate bacterial isolates from each plant roots, all plant roots were washed with sterilized distilled water in a test tube. A series of dilution $\left(10^{-1}, 10^{-2}\right.$ and $\left.10^{-3}\right)$ were made to reduce the density of the bacterial population. Each diluted sample was allowed to culture separately on a 9 $\mathrm{cm}$ petri dish containing a solid nutrient rich agar medium having sucrose, nutrient broth and agar at the rate of $10,10,15 \mathrm{gL}^{-1}$, respectively. The $\mathrm{pH}$ of the medium was 6.5 . Each media was autoclaved at $121^{\circ} \mathrm{C}$ with $15 \mathrm{psi}$ for 20 minutes before inoculation. After inoculation the samples were spreaded with the help of a sterile spreader and incubated in an incubator at $28^{\circ} \mathrm{C}$ for 2 days. Again bacterial isolate from soil samples were isolated using a liquid nutrient rich media prepared in a $500 \mathrm{~mL}$ conical flask and autoclaved at $121^{\circ} \mathrm{C}$ with $15 \mathrm{psi}$ for 20 minutes. Exactly $200 \mathrm{~mL}$ broth media was inoculated with approximately $2 \mathrm{~g}$ soil inoculums and incubated in an incubator at $28^{\circ} \mathrm{C}$ for 2 days. Then bacterial suspension was produced in the conical flask and then this suspension was spread in a solid nutrient agar medium with desired dilution. In this isolation each media was autoclaved at $121^{\circ} \mathrm{C}$ with $15 \mathrm{psi}$ for 20 minutes before inoculation. After inoculation the samples were spread with the help of a sterile spreader and then incubated in an incubator at $28^{\circ} \mathrm{C}$ for 2 days. After 2 days of the incubation morphologically different sized and shaped bacterial isolates were selected for the further culture with the help of a toothpick and pin pointed sterile needle. Pure cultures of the bacterial isolates were obtained by repeated sub-culture method. In this method, the bacterial isolates were grown repeatedly until a pure culture of a strain is obtained.

\section{Screening of the PSB}

Mineral phosphate solubilization activities of isolated bacterial isolates were tested by plate assay following Islam et al. (2007). Phosphorus solubilizing bacteria screening were done using NBRIP medium (Nautiyal, 1999). Phosphate solubilizing capacity was calculated in terms of phosphate solubilization index, $\mathrm{PSI}(\mathrm{PSI}=\mathrm{A} / \mathrm{B}$, where $\mathrm{A}$ is the total diameter of the halo zone, and $\mathrm{B}$ is the colony diameter) (Edi Premono et al., 1996). The isolates showing PSI $>2$ have been considered as phosphate solubilizing bacteria.

\section{Characterization of the bacterial strain}

\section{Morphological characterization}

For the morphological characterization the colony color, colony shape and elevation of the pure cultured bacterial isolate was determined. In order to characterize all the bacterial isolate was placed on the nutrient broth agar medium with help of a loophole. After the inoculation all the bacterial isolates were incubated in an incubator for 2 days at $28^{\circ} \mathrm{C}$. Two days after incubation all the bacterial colonies were observed with the help of a hand magnifying glass to identify their colony color, shape and edge shape.

\section{Biochemical characterization}

\section{Gram test}

On glass slide a loop full of bacteria from a well grown colony was mixed with a drop of $3 \%$ aqueous $\mathrm{KOH}$. Mixing was continued for less than 10 seconds. A toothpick was used for picking bacteria from a colony as well as for mixing it. The toothpick was raised a few centimeters from the glass slide. Strands of viscid material confirmed the bacterium was gram-negative (Ahmed, 2011).

\section{Catalase test}

Catalase is the enzyme that breaks hydrogen peroxide $\left(\mathrm{H}_{2} \mathrm{O}_{2}\right)$ into $\mathrm{H}_{2} \mathrm{O}$ and $\mathrm{O}_{2}$. Hydrogen peroxide is often used as a topical disinfectant in wounds and the bubbling that is seen is due to the evolution of $\mathrm{O}_{2}$ gas. $\mathrm{H}_{2} \mathrm{O}_{2}$ is a potent oxidizing agent that can wreak havoc in a cell; because of 
this, any cell that uses $\mathrm{O}_{2}$ or can live in the presence of $\mathrm{O}_{2}$ must have a way to get rid of the peroxide. One of those ways is to make catalase. A small amount of bacterial isolate was placed from culture onto a clean microscope slide. A few drops of $\mathrm{H}_{2} \mathrm{O}_{2}$ were added onto the smear. A positive result is the rapid evolution of $\mathrm{O}_{2}$ as evidenced by bubbling. A negative result is no bubbles or only a few scattered bubbles (Wheelis, 2008).

\section{Performance of selected PSB isolate on the rice seedling}

The bacterial isolates were selected to examine their performance on a test crop rice variety Iratom 24. On the basis of their PSI values three bacterial isolates were selected eg one with highest PSI (SB8), one with moderate PSI (SB15) and one with lowest PSI (SB25) and inoculated with the plant roots before transplanting. Seeds of Iratom 24 were surface sterilized by using $70 \%$ ethanol for 10 minutes, and $100 \%$ ethanol for five minutes, respectively. After every step seeds were washed by distilled water for five times. The seeds were then soaked in the bacterial suspension for 3 hours. The bacteria coated seeds were placed on petri dish containing sand for germination. Ten days old seedlings were transplanted in earthen pots and allowed to grow for 30 days. Every pot contained $10 \mathrm{~kg}$ soil was treated with recommended dose of urea, MoP, gypsum and TSP. The dose of TSP varied according to the treatments. Total P content and P concentration was determined after harvesting of seedlings.

\section{Treatments under investigations}

The conducted experiment was a two factor experiment viz. three PSB inoculants and different $\mathrm{P}$ doses. The nutrient broth containing no bacterial isolate was used as control. The treatment combinations were as follows:

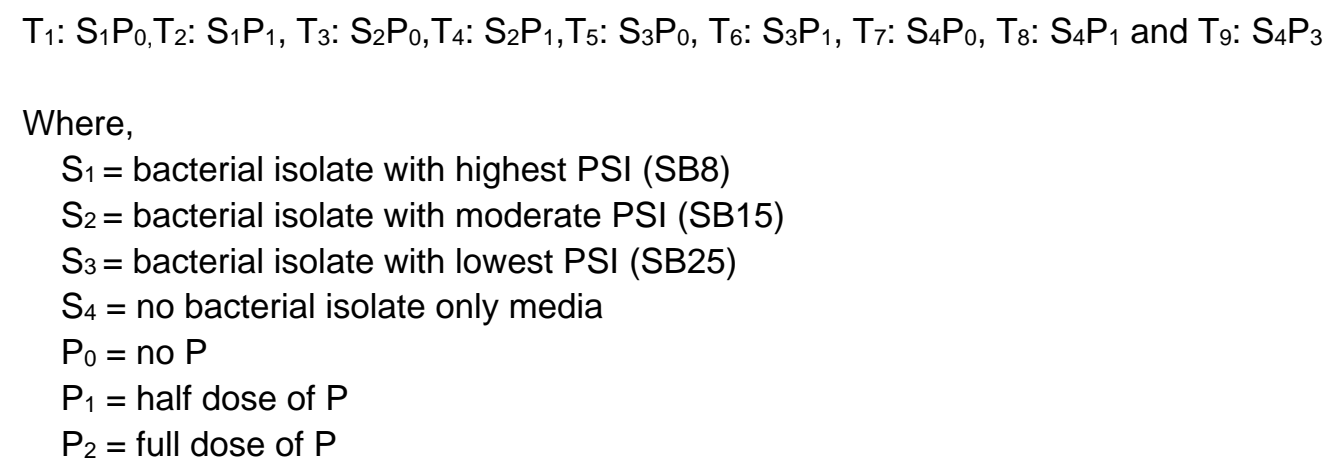

\section{Sample collection and processing}

Thirty days after transplanting one plant was sampled from each pot and labeled properly and sent directly to the laboratory for further processing and chemical analysis. Plant samples were washed several times with tap water followed by distilled water. After air drying (48 hours) and oven drying ( 48 hours at $60^{\circ} \mathrm{C}$ ) the samples were subjected to grinding $(0.2 \mathrm{~mm}$ sieve). The ground plant samples were then digested using $\mathrm{HNO}_{3}$ and $\mathrm{H}_{2} \mathrm{O}_{2}$ to obtain the plant extract for the determination of $\mathrm{P}$ content.

\section{Statistical analysis}

The statistical analysis of the experimental data was carried out using MS Excel and Mini Tab data analysis software. Statistical differences between treatments were carried out by Tukey's range test. 


\section{RESULTS AND DISCUSSION}

\section{Isolation of bacterial isolated from the contaminated sites}

Indigenous bacterial isolates from the contaminated site from Seedstore, Bhaluka, Mymensingh were isolated by culturing them on nutrient agar and nutrient broth medium. Thirty four pure bacterial isolates were isolated among which about 28 bacterial isolates were isolated from the plant roots and about 6 bacterial isolates were isolated from the soil. All bacterial isolates were designated as SB1 to SB34.

\section{Morphological characterization}

The morphology such as colony colour, colony shape and elevation of the bacterial isolates were observed. All bacterial isolates showed different colour such as greenish white, pinkish, creamy white, brownish, creamy, whitish, yellowish, yellowish cream and different shape such as round, irregular, curled and elevation as flat, umbonate, raised, convex, growth into medium. The most of the bacterial isolates were round shaped. The morphological characterization results of the bacterial isolates are given in the Table 1.

Table 1. Morphological characterization of the bacterial Isolates

\begin{tabular}{|ll|}
\hline Morphological properties & Strains \\
\hline Shape & SB1, SB2, SB3, SB4, SB5, SB6, SB8, SB9, SB10, SB11, SB13, SB14, \\
& SB16, SB17, SB18, SB19, SB21, SB22, SB24, SB25, SB26, SB27, \\
Irregular & SB28, SB29, SB30, SB31, SB33 \\
Curled & SB7, SB12, SB15, SB20, SB23 \\
& SB32, SB34 \\
Colour & \\
Greenish white & \\
Pinkish & SB1, SB3, SB4, SB5, SB6 \\
Brownish & SB2, SB23, SB25, SB30, SB34 \\
Creamy & SB7 \\
Whitish & SB8, SB15, SB16, SB17, SB18, SB24, SB27, SB31 \\
Yellowish & SB9, SB11, SB12, SB20, SB33 \\
Creamy white & SB10, SB13, SB14, SB19, SB21, SB26, SB29 \\
Yellowish cream & SB22, SB32 \\
& SB28 \\
Elevation & \\
Flat & \\
Umbonate & SB1, SB3, SB4, SB11, SB16, SB22, SB25, SB28 \\
Raised & SB2, SB12, SB23, SB26,SB27, SB29, SB34 \\
Growth into medium & SB5, SB7, SB8, SB10, SB14, SB21 \\
Convex & SB6, SB9, SB15, SB17, SB19, SB24,SB30, SB32, SB33 \\
\hline
\end{tabular}

\section{Biochemical characterization}

\section{Gram test}

The gram negativity of isolates was confirmed by potassium hydroxide solubility test. The result revealed that an elastic thread or viscous thread was observed when loop raised from the bacterial solution by toothpick a few centimeters from glass slides in case of all gram negative bacterial isolates. Maximum numbers of the bacterial isolates (25) were gram negative and rest of them were gram positive (Table 2). 


\section{Catalase test}

Catalase is a common enzyme found in nearly all living organisms exposed to oxygen (such as vegetables, fruit or animals). It catalyzes the decomposition of hydrogen peroxide to water and oxygen. It is a very important enzyme in protecting the cell from oxidative damage by reactive oxygen species (ROS) (Ahmed, 2011). Likewise, catalase has one of the highest turnover numbers of all enzymes; one catalase molecule can convert millions of molecules of hydrogen peroxide to water and oxygen each second. About 31 bacterial isolates were able to produce this enzyme (Table 2).

Table 2. Biochemical characterization of the bacterial isolates

\begin{tabular}{|ll|}
\hline $\begin{array}{l}\text { Biochemical } \\
\text { Characterization }\end{array}$ & Strains \\
\hline $\begin{array}{l}\text { Gram test } \\
\text { Gram }(-)\end{array}$ & SB1, SB2, SB3, SB5, SB6, SB7, SB8, SB9, SB10, SB11, SB13, SB14, SB15, \\
& SB16, SB17, SB19, SB20, SB21, SB22, SB25, SB26, SB27, SB31, SB32, \\
Gram (+) & SB34 \\
Catalase test & SB4, SB12,SB18, SB23, SB24, SB28, SB29, SB30, SB33 \\
Catalae (+) & \\
& SB1, SB2, SB3, SB4, SB5, SB6, SB7, SB8, SB9, SB10, SB11, SB12, SB13, \\
& SB14, SB15, SB16, SB19, SB21,SB22, SB23, SB24, SB25, SB26, SB27, \\
Catalae (-) & SB28, SB29, SB30, SB31, SB32, SB33, SB34 \\
\hline
\end{tabular}

\section{Phosphorous solubilizing capacity}

Phosphorous solubilizing capacities of 34 bacterial isolates were evaluated and 25 bacterial isolates were capable of mobilizing phosphorus from inorganic source (tri-calcium phosphate). Those bacteria can be used to increase $P$ availability in agricultural soils to improve plant's $P$ nutrition. The PSI of these isolates presented in Table 3 and Figure 2.

Strain SB8 gives the maximum PSI (11.42) whereas other bacterial isolate shows average result ranging from 1.75 to 6.36 . Islam et al. (2006) isolated some bacterial isolate where they found PSI ranging from 1.6 to 6.7. The ability of phosphate solubilization by plant-associated Pseudomonas, Klebsiella, Enterobacter and Microbacterium species have been reported in several papers. However, reports on root-associated Acinetobacter sp. and their phosphate solubilizing activity are very rare (Rodríguez and Fraga, 1999).

\section{Effect on the $P$ content and $P$ uptake of the plant}

The highest $P$ content was observed in treatment $\mathrm{S}_{4} \mathrm{P}_{2}$ about $0.3 \%$ and second highest was in $\mathrm{S}_{1} \mathrm{P}_{1}$ and $\mathrm{S}_{2} \mathrm{P}_{1}$ about $0.2 \%$ and lowest was in $\mathrm{S}_{3} \mathrm{P}_{0}$ about $0.1 \%$. Similarly highest $\mathrm{P}$ uptake was observed in $\mathrm{S}_{1} \mathrm{P}_{1}$ about $0.5 \mathrm{~g} \mathrm{plant}^{-1}$ and second highest was observed in $\mathrm{S}_{4} \mathrm{P}_{2}$ and $\mathrm{S}_{2} \mathrm{P}_{1}$ about $0.4 \mathrm{~g}$ plant $^{-1}$ and lowest was in $\mathrm{S}_{3} \mathrm{P}_{1}$ about $0.2 \mathrm{~g} \mathrm{plant}^{-1}$ which revealed that strain SB8 achieved $10 \%$ higher $\mathrm{P}$ uptake than control. The graphical presentation of $\mathrm{P}$ uptake and $\mathrm{P}$ content is presented in Figure 2.

Though P content was not highest in plants treated with bacterial isolates but total uptake was highest. This was may be due to the growth enhancement by the PSB (Shitepu et al., 2007). Phosphate solubilization was carried out by a large number of saprophytic bacteria and fungi acting on sparingly soluble soil phosphates, mainly by chelation-mediated mechanisms (Whitelaw, 2000). Inorganic $P$ is solubilized by the action of organic and inorganic acids secreted by PSB in which hydroxyl and carboxyl groups of acids chelate cations (Al, Fe, Ca) and decrease the $\mathrm{pH}$ in basic 
soils (Stevenson, 2005). The PSB dissolve the soil P through production of low molecular weight organic acids mainly gluconic and ketogluconic acids (Deubel et al., 2000), in addition to lowering the $\mathrm{pH}$ of rhizosphere. The $\mathrm{pH}$ of rhizosphere is lowered through biotical production of proton I bicarbonate release (anion / cation balance) and gaseous $\left(\mathrm{O}_{2} / \mathrm{CO}_{2}\right)$ exchanges. Therefore, these PSB may be efficiently used in field to available fixed $P$ from the soil. As a result application of $P$ fertilizer will be reduced and this will increases the fertilizer use efficiency.
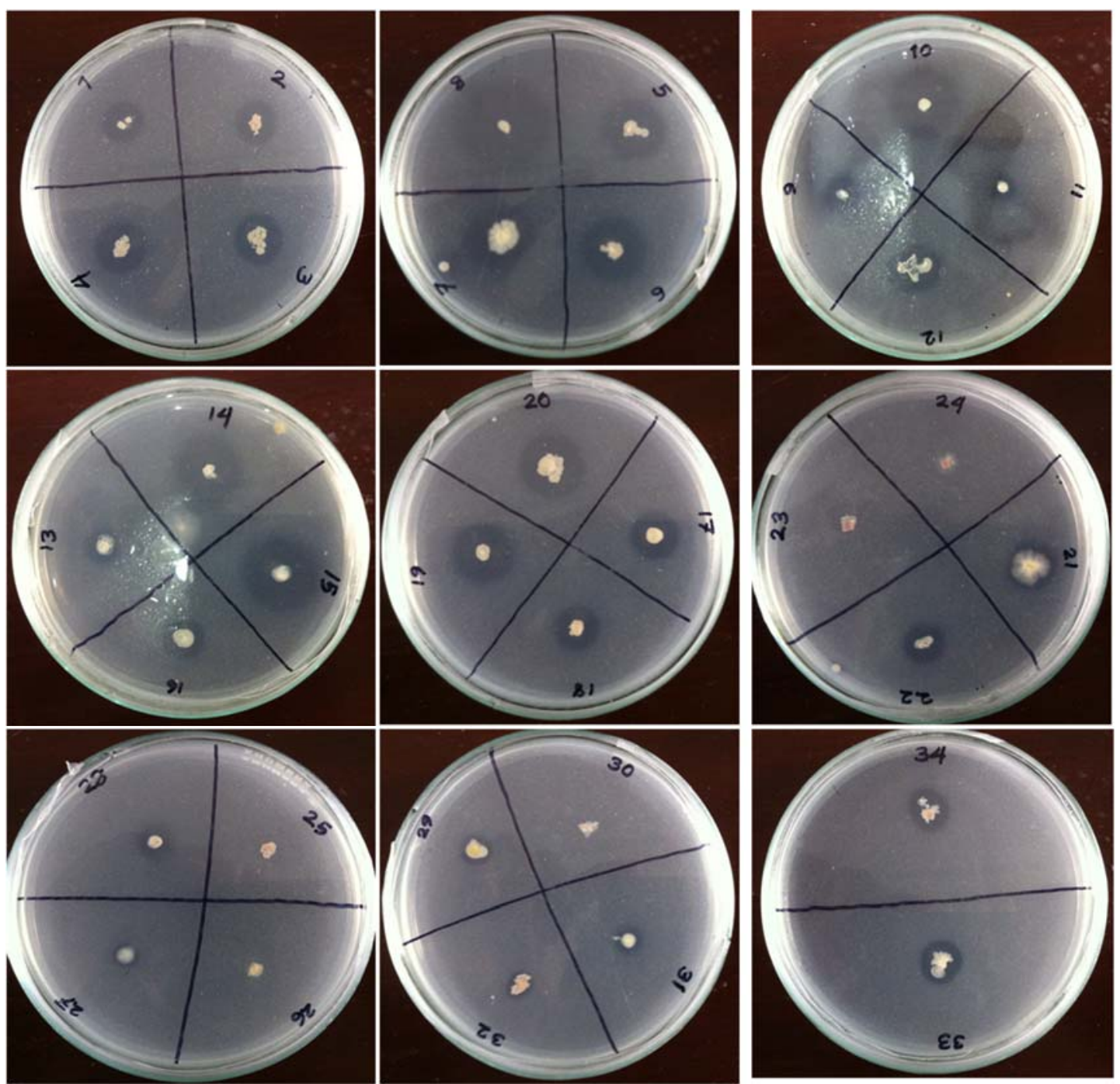

Figure 1. Phosphate solubilization by isolated rhizo bacteria on NBRIP media. The halo zone around the bacterial colony indicates $\mathrm{P}$ solubilization by the bacteria.

Table 3: PSI of the bacterial isolates after 7 days

\begin{tabular}{|ll|}
\hline PSI value & Strains \\
\hline $0.0-4.0$ & SB3, SB5, SB6, SB11, SB13, SB16, SB17, SB18, SB19, SB20, SB23, \\
& SB24,SB 25, SB26, SB27, SB28, SB29, SB30, SB31, SB32, SB33, SB34 \\
$4.0-8.0$ & SB1, SB2, SB4, SB7, SB9, SB10, SB12, SB14, SB15, SB21, SB22 \\
$8.0-12.0$ & SB8 \\
\hline
\end{tabular}




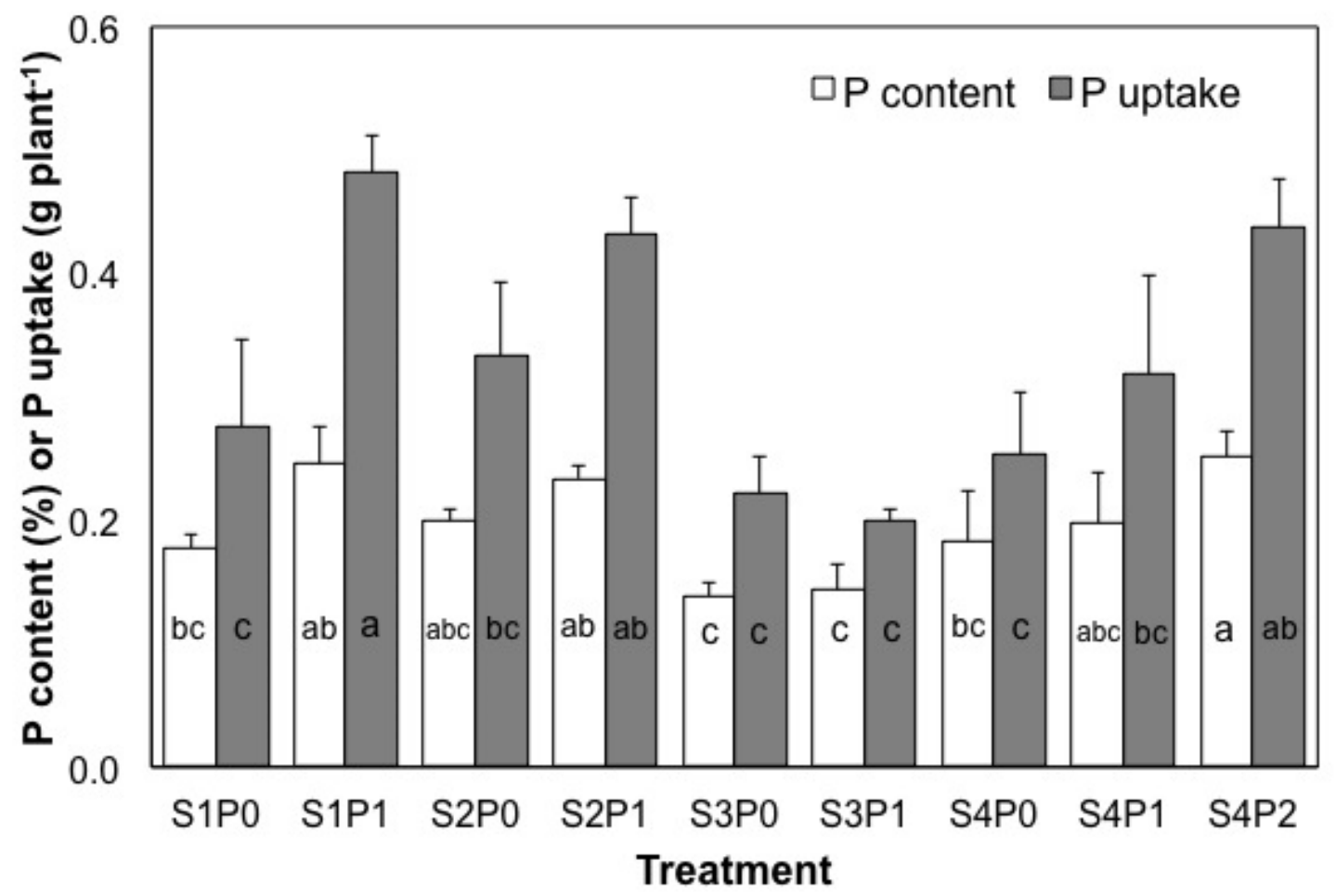

Figure 2. Effect of different bacterial isolates on the $P$ content and $P$ uptake by rice plant. Columns with different letters are statistically different and vice versa. Bars are indicating standard deviations. S1, S2, S3 and S4 stand for SB8, SB15, SB25 and chemical fertilizer, respectively.

\section{CONCLUSION}

Bacterial isolates were grown on a NBRIP media containing $\mathrm{Ca}_{3}\left(\mathrm{PO}_{4}\right)_{2}$ for seven days to determine their phosphorus solubilizing capacity and their PSI was determined. Twenty five bacterial isolates were identified as PSB among which Strain SB8 showed highest PSI about 11.42 and rest of the strains PSI ranged from 1.75 to 6.36. On the basis of PSI, three strains were selected such as one highest PSI, one moderate PSI strain and one no PSI strain i.e. SB8, SB15 and SB25, respectively and they were treated with zero $P$ and half $P$ of the recommended doses of $\mathrm{P}$ and a control (without any bacterial isolate) treated with zero $\mathrm{P}$, half $\mathrm{P}$ and full $\mathrm{P}$ of the recommended doses of $\mathrm{P}$ to determine their effect on the growth and $\mathrm{P}$ uptake of test crop rice $\mathrm{cV}$. Iratom 24. Though there was no significant difference was found on the shoot and root length, number of tillering and shoot dry weight but significant difference was observed on the $\mathrm{P}$ content and $\mathrm{P}$ uptake among the treatments. The highest $\mathrm{P}$ content was observed in treatment $\mathrm{S}_{4} \mathrm{P}_{2}$ about $0.3 \%$ and second highest was in $\mathrm{S}_{1} \mathrm{P}_{1}$ and $\mathrm{S}_{2} \mathrm{P}_{1}$ about $0.2 \%$ and lowest was in $\mathrm{S}_{3} \mathrm{P}_{0}$ about $0.1 \%$. Similarly highest $P$ uptake was observed in $S_{1} P_{1}$ about $0.5 \mathrm{~g}$ plant $^{-1}$ and second highest was observed in $\mathrm{S}_{4} \mathrm{P}_{2}$ and $\mathrm{S}_{2} \mathrm{P}_{1}$ about $0.4 \mathrm{~g}$ plant ${ }^{-1}$ and lowest was in $\mathrm{S}_{3} \mathrm{P}_{1}$ about $0.2 \mathrm{~g} \mathrm{plant}^{-1}$ which revealed that strain SB8 achieved $10 \%$ higher $\mathrm{P}$ than control.

Thirty four bacterial isolates from a contaminated site has been isolated and their $P$ solubilizing capacity evaluated. Further studies may be undertaken to explore the possibility of isolation of more effective $\mathrm{P}$ solubilizing isolates for compensating the $\mathrm{P}$ fixation problem in soil and exploring the plant species with where a desirable symbiotic relation between plant and bacterial isolate might be possible and potentials in the field applications. Advanced molecular studies are needed to identify bacterial isolates through 16s rRNA gene sequencing and also to elucidate the $P$ solubilizing mechanisms of isolated strains. 


\section{COMPETING INTEREST}

The authors declare that they have no competing interests.

\section{ACKNOWLEDGEMENTS}

The research work was funded by Ministry of Science and Technology (MOST), Bangladesh and HEQEP-AIF sub-project (CP2013). Authors would like to thank Mr. Istiaq Ahmed for his kind assistance during the conduction of the research work.

\section{REFERENCES}

1. Ahmed I, 2011. Isolation and characterization of As resistant bacteria from the contaminated soil and their effects on seed germination of rice, Ms Thesis, Department of Agricultural Chemistry, Bangladesh Agricultural University.

2. Beever RE and DJW Burns, 2000. Phosphorus uptake, storage and utilization by fungi. Advance Botany Research, 8: 127-219.

3. Deubel A, A Gransee and W Merbach, 2000. Transformation of organic rhizodeposits by rhizoplane bacteria and its influence on the availability of tertiary calcium phosphate. Journal of Plant Nutrition and Soil Science, 163:387-392.

4. Edi PM, AM Moawadand PLG Vlek, 1996. Effect of phosphate-solubilizing Pseudomonas putidaon the growth of maize and its survival in the rhizosphere. Indonesia Journal of Crop Science, 11:13-23.

5. Fasim F, N Ahmed, R Parson and GM Gadd, 2002. Solubilization of zinc salts by a bacterium isolated from air environment of a tannery. FEMS Microbiology Letters, 213:1-6.

6. Glick BR, 1995. The enhancement of plant growth by free-living bacteria. Canadian Journal of Microbiology, 41: 109-117.

7. Gyaneshwar P, GN Kumar, LJ Parekh and PS Poole, 2002. Role of soil microorganisms in improving $P$ nutrition of plants. Plant and Soil, 245: 83-93.

8. Halder AK, AK Mishra, P Bhattacharya and PK Chakrabarthy, 1990. Solubilization of rock phosphate by Rhizobium and Bradyrhizobium. The Journal of General and Applied Microbiology, 36: 81-92.

9. Hilda R and R Fraga (1999): Phosphate solubilizing bacteria and their role in plant growth promotion. Biotechnology Advances, 17: 319-359.

10. Kim KY, D Jordan and HB Krishnan, 1997. Rahnellaaqualitis, a bacterim isolated from soybean rhizosphere, can solubilize hydroxyapatite. FEMS Microbiology Letters, 153: 273-277.

11. Kpomblekou K, and MA Tabatabai, 1994. Effect of organic acids on release of phosphorus from phosphate rocks. Soil Science, 158: 442- 453.

12. Mahantesh $P$ and CS Patil, 2011. Isolation and biochemical characterization of phosphate solubilizing microbes. International Journal of Microbiology Research, 3: 67-70.

13. Reyes I, L Bernier, R Simard and H Antoun, 1999. Effect of nitrogen source on solubilization of different inorganic phosphates by an isolate of Pencillium rugulosum and two UV-induced mutants. FEMS Microbiology Ecology, 28: 281-290.

14. Richardson AE, 2001. Prospects for using soil microorganism to improve the acquisition of phosphorus by plants. Australian Journal of Plant Physiology, 28: 897-906.

15. Rodriguez $\mathrm{H}$ and $\mathrm{R}$ Fraga, 1999. Phosphate solubilizing bacteria and their role in plant growth promotion. Biotechnology Advances, 17:319-39.

16. Sitepu IR, Aryanto, N Ogita, M Osaki, E Santoso, S Tahara and Y Hashidoko, 2007. Screening of rhizobacteria from dipterocarp seedlings and saplings for the promotion of early growth of Shoreaselanica seedlings. Tropics, 16: 245-252.

17. Stevenson FJ, 2005. Cycles of Soil: Carbon, Nitrogen, Phosphorus, Sulfur, Micronutrients, John Wiley and Sons, New York.

18. Wheelis M, 2008. Principles of modern microbiology, Jones and Bartlett Publishers, Inc., Sudbury, MA.

19. Whitelaw MA, 2000. Growth promotion of plants inoculated with phosphate solubilizing fungi. Advance Agronomy, 69: 99-151. 